\title{
Effect of montessori method of teaching on junior secondary students' Achievement in measuration in education Zone B, Benue State of Nigeria.
}

\author{
${ }^{* 1}$ Kurumeh, M.S, ${ }^{1}$ Agogo, P.O and ${ }^{2}$ Usman, K \\ ${ }^{1}$ Mathematics Unit, Department of Curriculum and Teaching, Faculty of Education, \\ Benue State University, Makurdi, Nigeria. \\ *seraphinakurumeh@yahoo.com, +2348062676626, \\ dr.peteragogo@yahoo.com, +2348037400785 \\ ${ }^{2}$ Department of Mathematics \& Computers, Benue State University, Makurdi, Nigeria \\ usmank4real@yahoo.co.uk +2348054448047
}

\begin{abstract}
This study determined the effectiveness of Montessori Method of Teaching, MMT on Junior Students' achievement in measuration. The study was carried out in Education Zone B of Benue State, Nigeria using a sample size of 224 junior secondary 1(JSS1) students. It was a non equivalent quasi-experimental study which was guided by two research questions and three hypotheses. The instrument Measuration Achievement Test (MAT) constructed by the researchers with a reliability coefficient of 0.76 was used as pre and post tests though reshuffled each time. Mean and standard deviation were used in answering the research questions while the hypotheses were tested at $P<.05$ using a 2-way analysis of covariance (ANCOVA). Results from the analysis revealed that students exposed to MMT were superior in achievement than those taught with Conventional Method. Thus there was significant difference between the mean scores of students taught measuration with MMT and those taught with the Conventional in achievement $\left(F_{1,223}=113.376, p=0.000\right)$. Gender was also found statistically significant $\left(F_{1,223}=9.129 .003\right)$. The study therefore recommended training of mathematics teachers on the use of Montessori Method in their daily lesson especially in measuration with a view to making learning of mathematics meaningful, relevant and interesting.
\end{abstract}

Keywords: Montessori Method of teaching, achievement, measuration, teaching methods, measuration achievement test.

\section{INTRODUCTION}

The world is a global village. This has made science and technology very essential in every nation. Mathematics being the queen of science and technology cannot be left behind hence the need to acquire the knowledge of mathematics all over the world.

Mathematics is not only vital in science and technology but very essential in everyday living and in various disciplines. Hardly a day will pass without one encountering mathematical calculation in one way or the other e.g. in the market, school, meeting, on the road and in the household activities (Azuka, 2003).

On account of its importance in daily living and in the national economy, Nigerian government has made mathematics compulsory as a core course in 9 year basic education. Unfortunately, Nigerian students persistently score very low in mathematics both in internal and external examinations especially in Education Zone $B$ of Benue State in Nigeria (Kurumeh, 2006). The failure rate was so high that Nigeria was found to occupy the second to the last position when compared with the eleven other English speaking West African countries in mathematics in School Certificate Examination (Abakpa and Agbo-Egwu, 2008). Researchers like Harbor-Peters (2001), had discovered use of inappropriate teaching method as one of the factors responsible for such incessant failure in mathematics. WAEC Chief Examiners had recommended that the use of teaching methods that are practical, learner centered, activity-based and meaningful to the needs of the learner might result in better performance in mathematics (NCTM, 2000, WAEC, 2006 ). This recommendation seems to call for an option of giving Montessori Method of Teaching (MMT) a trial being a practical approach that has the interest of the learner 
at heart. This study then wants to determine the effectiveness of Montessori Method of Teaching in facilitating students' achievement in measuration among Junior secondary students in Education Zone B of Benue State in Nigeria.

Montessori Method of Teaching (MMT) is a scientific approach to pedagogy introduced by Maria Montessori in 1907 in Italy. Here learners are provided with didactic materials which are various artifacts they can use to educate themselves. They are allowed as much freedom as possible and are supervised by a single directress whose primary duty is only to observe and direct the activities or the efforts of the learners by explaining to them how various didactic materials are used. This approach addresses the learners' most pressing challenges or needs such as engaging and motivating learners, teaching learners of varying ability, utilizing technology in the classroom, and balancing students' understanding. It is an example of self-directed approach to learning. According to Abuul (2008), the method is characterized by an emphasis on selfdirected activity on part of the learner and clinical observation on the part of the teacher.

This approach achieved startling results with 312 year old children. Learning is to enable them to master it themselves, be disciplined, benevolent, self confident and capable of reading and writing (Montessori, 2004). This approach is a wonderful approach the learner cannot afford to miss, Maria Montessori believes in children learning at their pace and in their own fashion (Montessori, 2003). Learning here is without barriers. There exist environment that is warm, happy, full of love that would bring about happy and healthy children. It takes advantage of the children's sensitive years between 3-12 years when they can absorb information from an enrich environment.

In A Montessori classroom, learning equipments are specially prepared to suit the environment. This learning environment stimulates and encourages the child to learn. Children enjoy using Montessori materials to learn because they are colorful, concrete and solid as well as stimulates interest. Learning is by associating abstract concept with concrete sensorial experience not by memorization.

The prepared environment of Montessori is supplied with didactic materials which are manipulated by the children. The materials are designed to foster independent, interest, develop a healthy self concept, encourage reflective thinking, provide an appreciation of nature and the world. The prepared environment includes the practical life, the sensorial, language art, mathematics and culture. The exercises of the practical life are the foundation of the Montessori philosophy for future academic learning. They encompass a great diversity of activities to help child develop greater concentration and independence. The involvement and full participation of the learners makes learning by this approach unique.

The child has, in this classroom, the opportunity to participate in caring for the environment e.g. sweeping, dusting washing tables, caring for plants etc. The child learns also to care for self, washing hands, preparing and serving snacks, folding classroom towels, dressing etc, Variety of activities are designed sequentially to enable the child to come to realize order and logic in the classroom environment . Concentration, attention, order, independence and muscular coordination originate with this work. The child may repeat the sequence of each activity independently to develop these qualities. This classroom is characterized by an atmosphere that is warm, happy, relaxed and full of love that would bring about happy healthy children, full of productive activities. Learning here is easy, no pressure is applied. Learners watch, observe, practice and discover for themselves step -by - step , calmly, peacefully and assist one another.

The Montessori Sensorial materials offer a wealth of concrete objects to manipulate word which sequentially lead to abstract concepts. They provide materialized abstraction that are the groundwork for the concepts of number and numeral. The sensorial area gives the learner a perceptional idea of basic mathematics. It is an indirect preparation for mathematics. It helps them to learn to perceive minute differences between objects thereby training his senses to create an astute observer. Mathematics materials are concrete activities using rods, beads, spindles, cubes, golden beads etc that can be used to learn and count with structure of numbers. All are logical, gradual, step- by - step, moving from concrete to abstract, from known to unknown and internalization of mathematical relationship of the world in which we live.

Research Questions: The following research questions guided the study:

1. What is the relative effect of the use of Montessori Method of teaching, (MMT) and Conventional teaching method on students mean achievement scores in measuration? 
2. What is the relative effect of the use of Montessori Method of teaching and the Conventional teaching method on the mean achievement scores of male and female students in measuration?

\section{Research Hypotheses:}

The following null hypotheses were formulated and tested at $\mathrm{P}<.05$ fur the study:

$\mathrm{Ho}_{1:}$ There is no significant difference in the mean achievement scores of students taught measuration using MMT and those taught using Conventional approach.

$\mathrm{Ho}_{2}$ : There is no significant difference in the mean achievement scores of male and female students taught measuration using MMT and those taught using Conventional approach.

$\mathrm{Ho}_{3}$ : There is no significant interaction effect between sex and group in measuration using MMT

\section{MATERIALS AND METHODS:}

This study took place in Education Zone B of Benue State, Nigeria (2008/2009 academic session). It was non equivalent Pretest Posttest Control group design. There was no randomization of subjects since this may disrupt school organization, hence, intact classes were randomly assigned to experimental and control groups respectively.

The population of this study comprise of all JSS1 students (2008/9 session) Education Zone B of Benue State, Nigeria. This target population is restricted to only government Junior secondary schools in this Education Zone who are using UBE Curriculum.

The sample for this study comprise of 224 JSS1 students selected randomly from four junior secondary schools in this Zone by balloting. In each school selected, two intact classes were drawn randomly and assigned to experimental and control groups using simple balloting. The experimental group was taught measuration using Montessori method of teaching (MMT) while the control group was taught the same topic using Conventional Approach (CA).

The instrument used in the study was Measuration Achievement Test (MAT) which was both face and content validated. The validation was done by three experts in measurement and evaluation and three in mathematics education. They were instructed to check for the language level, relevance, ambiguity, plausibility, vagueness and content coverage of the instrument for the study. Their advice, comments, recommendations and suggestions were used to modify MAT.

At the end of validation, 25 out of 46 initial items survived for the study. This MAT was comprehensively developed by the researcher based on the test blueprint and Jss1 scheme. The instrument, MAT, was then administered to 25 students in another school who were not part of the study as pilot study. The reliability coefficient of MAT using Kuder-Richardson (21) was 0.74. This was considered reliable enough to be used for the study (Pallat, 2001).

Two regular mathematics teachers from each of the schools were used as research assistants to teach the students. These research assistants were trained by the researcher for three days before the commencement of the study. The training exercise was based on the purpose of the study, the topic to be taught, the use of lesson plans, the use of the MAT and the general conduct of the study. They were trained to teach both the experimental and the control groups. Those to teach the experimental groups were exposed to all the intricacies of Montessori Method of teaching, its use of Montessori tools for measuration, its setting and independence or freedom and interaction in learning. Those to teach the control group were to use the normal approach called Conventional approach. The teachers administer MAT as pretest before the commencement of the lesson to the students in each class.

In the experimental group, the teacher after administering MAT as pretest, begins to use the lesson plans as prepared by the researchers allowing the learners to freely manipulate the mathematics materials as stipulated in the lesson plans. The students practice and master each concept or skills one after the other using the materials provided. With each successive material and lesson, the students move from very concrete (hands on) work to more abstract work without much difficulty. The students have opportunity to practice independently until they master or understand the skills or concepts in question using varieties of materials

The study lasted for one week of five periods of 40 minutes per lesson. At the end of the five lessons taught, MAT was administered as post test for both subjects of experimental and control groups. The MAT was collected and used for analysis. 


\section{RESULTS}

The results of the study were presented according to the research questions and the associated hypotheses.

Table 1 shows that the mean achievement scores of students taught using MMT was 60.95, with standard deviation of 11.17 while that of students taught with conventional approach was 44.11with standard deviation of 14.31. This seems to suggest that students taught using MMT appeared to have higher mean achievement scores than their control group counterparts. This implies that MMT is more efficacious than the Conventional Approach. Results in Table 2 revealed that the noted difference between the mean achievement scores of those taught with MMT and those taught with the Conventional approach is significant at $p<.05$ level. The result further showed that $36.1 \%$ (Adjusted R Squared
$=.361$ ) of the variation in achievement in measuration was accounted for by MMT between the groups. Hence Hypothesis 1 was therefore rejected.

The results in table 1 and 2 showed that the mean achievement scores of the male student was 61.33 with standard deviation of 11.57 while that of the female students was 60.48 with standard deviation of 10.78 in the posttest using MMT. The difference in their mean achievement scores seemed to favor the males using MMT. This difference in gender (sex) was found to be significant statistically (see Table 2) at $p<.05$. Therefore null hypothesis 2 was rejected.

There is interaction between sex and group and this interaction effect is statistically significant at $p<.05$. Hence null hypothesis 3 was rejected

Table 1: Mean Achievement Scores and Standard Deviation for Experimental and Control groups pre- and post-MAT

\begin{tabular}{|c|c|c|c|c|c|}
\hline Teaching Method & Type of test & Sex & $\mathbf{N}$ & Mean & SD \\
\hline \multirow{6}{*}{ Experimental } & \multirow[t]{3}{*}{ Pretest } & Male & 60 & 13.00 & 8.91 \\
\hline & & Female & 50 & 10.64 & 5.99 \\
\hline & & Total & 110 & 12.23 & 7.85 \\
\hline & \multirow[t]{3}{*}{ Posttest } & Male & 60 & 61.33 & 11.57 \\
\hline & & Female & 50 & 60.48 & 10.78 \\
\hline & & Total & 110 & 60.95 & 11.17 \\
\hline \multirow{6}{*}{ Control } & \multirow[t]{3}{*}{ Pretest } & Male & 40 & 12.35 & 8.35 \\
\hline & & Female & 74 & 10.53 & 6.33 \\
\hline & & Total & 114 & 11.17 & 7.12 \\
\hline & \multirow[t]{3}{*}{ Posttest } & Male & 40 & 37.95 & 14.74 \\
\hline & & Female & 74 & 47.43 & 13.00 \\
\hline & & Total & 114 & 44.11 & 14.31 \\
\hline
\end{tabular}

Table2 Two Way ANCOVA Result on Subjects Achievement scores in Post MAT

\begin{tabular}{|l|l|l|l|l|l|l|}
\hline Source of Variance & Sum of Squares & Df & Mean Squares & F & Sig & Decision \\
\hline Corrected Model & 19609.99 & 4 & 4902.49 & 32.51 & 0.000 & S \\
\hline Intercept & 140414.84 & 1 & 140414.84 & 930.983 & 0.000 & S \\
\hline Pretest & 1379.37 & 1 & 1379.37 & 9.146 & 0.000 & S \\
\hline Sex & 1376.90 & 1 & 1376.90 & 9.129 & 0.003 & S \\
\hline Group & 17099.79 & 1 & 17099.79 & 113.38 & 0.000 & S \\
\hline Sex: Group & 1296.94 & 1 & 1296.94 & 8.599 & 0.004 & S \\
\hline Error & 3303.50 & 219 & 150.824 & & \\
Total & 667104.00 & 224 & & & \\
Corrected Total & 52640.50 & & & & \\
\hline
\end{tabular}

a. $\mathrm{R}$ Squared $=.373$ (Adjusted $\mathrm{R}$ Squared $=.361$ )

$\mathrm{S}$ means significant at $\mathrm{P}<.05$ 


\section{DISCUSSION}

The study has shown that students taught measuration with MMT had higher mean achievement score (60.95) than their counterparts taught with Conventional approach (44.11) mean achievement score. This was further confirmed by the results in Table 2 which revealed that the difference in achievement between the experimental and Control groups was statistically significant $\left(F_{1,223}=\right.$ $113.376, p<.000)$. The reason for this high level of achievement must have been because of friendliness, the use of practical and concrete objects that brought the lesson home to the learner which goes beyond rote memorization. This finding is in agreement with the recommendations of NCTM (2000) and Chief Examiners of WAEC (WAEC, 2006) who expressed that using concrete and practical approach in teaching mathematics topics lead to greater understanding and meaningful learning that results in better performance. This too has proved MMT an appropriate and effective approach in agreement with Harbor-Peters (2001).

The result in Tables $1 \& 2$ further indicates that there was a difference in the mean achievement score of male and female students using MMT in favor of the males (61.33). This mean difference in favor of the males is also statistically significant. This is in line with Montessori (2003) which says that this approach allows freedom and interaction for the learners in the classroom.

\section{CONCLUSION;}

Since Montessori Method of teaching has proved more effective and superior in promoting students' achievement in measuration than the conventional method, this study recommends training of mathematics teachers on the use of MMT in daily lesson especially in measuration with a view to making learning of mathematics meaningful, relevant andinteresting.

\section{REFERENCES:}

Abakpa, P.O and Agbo-Egwu, A.O. (2008). The effect of small group Co-operative learning on students' achievement and retention in mathematics achievement tests. Benue Journal Research of Science Education. 1(1):71-80.

Abuul, S.I. (2008). Montessori Method of teaching mathematics . In Kurumeh M.S and Opara, M.F. Innovative teaching approaches of mathematics education in the $21^{\mathrm{ST}}$ Century Vol. 2. M.akurdi: Azaben Publishers Ltd

Azuka, B.F. (2003). The challenges of mathematics in Nigerian economic and technical development; Implication for tertiary education. ABACUS; Journal of Mathematical Association of Nigeria. 28(1): 18-20.

Harbor-Peters, V.F.A. (2001). Inaugural lecture; Unmasking some aversive aspects of school mathematics and strategies for averting them. Enugu; Snaap Press Ltd.

Kurumeh, M.S. (2006). Effect of Ethnomathematics Approach on students' achievement in geometry and mensuration. ABACUS, Journal of mathematical Association of Nigeria. (); 35- 44.

Montessori, M. (2003). Montessori Method Book .Berne Nobles

Montessori, M. (2004). The Montessori Method; Scientific pedagogy as applied to child education in children's House, New Delhi, Cosmos

National Council Teachers of mathematics (2000),

Pallant, J. (2001). SPSS survival Manual; A step by step Guide to data analysis using SPSS for windows (version 10 and 11). Berkshire UK; Open University Press.

WAEC (2006). Annual Analysis of WAEC Results, Lagos, Yaba

Press 